\title{
Studying the Effect of Operating Parameters on the Removal of Nickel Ion from an Adsorber by Using COMSOL Multiphysics Simulation
}

\author{
Mustafa M. Hathal ${ }^{1 *}$, Basim O. Hasan ${ }^{2}$
}

\begin{abstract}
Authors affiliations:
$1 *)$ Department of environment, Industrial development and management, The Ministry of Industry and Minerals, BaghdadIraq.

mus.mhathal@gamil.com
\end{abstract}

2) Department of Chemical

Engineering, Al-Nahrain University, Baghdad-Iraq.

basimohasan13@gmail.com

\section{Paper History:}

Received: $18^{\text {th }}$ June 2020

Revised: $20^{\text {th }}$ July 2020

Accepted: $25^{\text {th }}$ Sep. 2020

\begin{abstract}
The heavy metals are considered dangerous pollutants which harm health and environment. The adsorption process is the cost effective process to get-rid of heavy metal efficiently. In this study, the adsorption bed of Nickel is simulated by using COMSOL Multiphysics to find the effect of different operating parameters namely; flow rate, temperature and pollutant concentration on adsorption bed efficiency. The modeling of non-isothermal adsorption bed based on experimental isotherms kinetic of previous work is developed too. The results showed that the optimal conditions to generate maximum removal efficiency of heavy metal were at $50^{\circ} \mathrm{C}$ inlet temperature, $0.1 \mathrm{M}$ inlet concentration, and 80 $\mathrm{ml} / \mathrm{min}$ flow rate to achieve removal values higher than $50 \%$ of long operation period time.
\end{abstract}

Keywords: Heavy Metal Removal, Nickel, CFD, Adsorption, Operating Temperature.

main effects of $\mathrm{Ni}$ inhalation and [7]. To reduce toxic effects of $\mathrm{Ni}$ heavy metal, it is important to utilize $\mathrm{Ni}$ removal process. Nickel ions can be removed by using chemical deposition, coagulation, ion exchanging, flocculation, membrane separation, adsorption and electrochemical deposition, and physical adsorption are the most economical techniques among these methods [8]. Adsorption is carried between suspensions and solid surface, adsorbate molecules (salute molecules) are attracted to solid surface called adsorbent of high surface area per gram [9]. Chemical interaction bonds, hydrophobic forces, hydrogen ponds and van der walls charge forces usually have important role in adsorption process [10]. Adsorbent is selected by different parameters such as: adsorption loading, regeneration configurations, selectivity and material cost [8]. Adsorption has wide applications for heavy metal removal, a lot of investigators used different adsorbent to remove Ni such as: In 2000, Ajmal et al [11] used orange peel to obtain $158 \mathrm{mg} / \mathrm{g}$ loading capacity. Faur-Brasquet et al [12], investigated in 2002 the effect of activated carbon cloths in which $8.85 \mathrm{mg} / \mathrm{g}$ adsorbent loading was resulted. In 2003, Mavrov et al [13] used synthetic zeolite, the loading capacity was $60 \mathrm{mg} / \mathrm{g}$. Malkoc and Nuhoglu [14] used in 2005 tea factory waste to obtain 15.26 $\mathrm{mg} / \mathrm{g}$ loading capacity. In 2005, Kobya et al [15] used apricot stone to obtain $27.21 \mathrm{mg} / \mathrm{g}$ loading capacity. In 2009, Chen et al. [16] used multi walled carbon nanotubes/ iron oxide to obtain $9.18 \mathrm{mg} / \mathrm{g}$

NJES is an open access Journal with ISSN 2521-9154 and eISSN 2521-9162

This work is licensed under a Creative Commons Attribution-NonCommercial 4.0 International License 
loading capacity. Byeon et al [17] used in 2009 modified activated carbon to have $151.3 \mathrm{mg} / \mathrm{g}$ loading capacity. Kasaini et al [18] used in 2013 activated carbon modified by oxalate ions to obtain $50.76 \mathrm{mg} / \mathrm{g}$ loading capacity and in 2016, Lakherwal et al [19] used activated carbon to obtain $7.7 \mathrm{mg} / \mathrm{g}$ loading capacity. However, the main disadvantage of adsorption process is continuous accumulation of salute molecules (heavy metals) [20]. Accumulated amount of $\mathrm{Ni}$ can be used for industrial utilization staff such as catalysts [21].

For Ni removal from drinking water, PAC and GAC have higher efficiency and high economical function [22]. Activated carbon has maximum surface area value of $2000 \mathrm{~m}^{2} / \mathrm{g}$ and density $500 \mathrm{~g} / \mathrm{ml}$ at dry condition for both powder activated carbon (PAC) and granular activate carbon (GAC) [23]. Activated carbon is used to remove heavy metals such as $\mathrm{Pb}, \mathrm{Ni}$ and $\mathrm{Cu}$ from drinking water as motioned in Kadirvelu et al. [24]investigation. Activated carbon adsorption efficiency depends mainly upon the high surface area which is promotes higher amount of micro-size pores in additions to acidic behavior of adsorption solid surface forms typical bonds between adsorption and solute molecules such as $\mathrm{Ni}$ [17].In addition to higher surface area per gram, activated carbon has higher class porosity development with multi- spectrum of structure functional groups which promotes higher pollutant cleaning rate [25]. While activated carbon/ silica composite was used to remove heavy metals [25].

Many of investigators used theoretical analysis to model the adsorption process by correlating simple numerical simulation of heavy metal removal from industrial waste water by Paliulis, [26]. Other investigators used numerical solution by using CFD packages to obtain the concentration profile through adsorption bed such as: Tapia and Diaz-viera, [27] used COMSOL Multiphysics to model the adsorption solute in homogeneous matrix to study the numerical effects of transport parameters on adsorption process in which the linear and cubic isotherms empirical expressions were used. Computation fluid dynamic (CFD) simulation of adsorption bed has a good agree with experimental work as observed in Nouh et al., [28] who modeled $\mathrm{CO}_{2}$ removal by using adsorption bed by using ANSYS CFD package in which the validation between experimental work and the simulation was less than $2.5 \%$. Unfortunately, most of adsorption simulation in previous work investigations assumed that the adsorption bed has isothermal operation by using empirical mechanisms called isotherms like Elsworth, [29] used Langmuir isotherm empirical kinetic in COMSOL Multiphysics to model sulfur adsorption. The developing of empirical adsorption kinetics as function of temperature and $\mathrm{pH}$ was studied by Saad et al., [30].

The purpose of the present work is: (1) to model adsorption bed based on experimental data of Kasaini et al., [18] using adsorption mechanism parameter and transport equations, (2) to obtain the adsorption behavior for various operational parameters (inlet concentration, flow rate, and inlet temperature), (3) to optimize the most appropriate operation condition within transient study, and (4) to develop a novel modeling of adsorption bed of noisothermal condition from experimental data of isotherms parameters by using COMSOL Multiphysics V 5.4

\section{Theoretical Analysis}

The basic physics of adsorption bed modeling are fluid flow through porous media and mass transport of diluted solution through porous media. The heat transfer through porous media has been added to in present investigation to imitate the complexity of transport phenomena of three physics in adsorption bed. The main transport equations of present study can be expressed as follows [29]:

Continuity equation

$$
\frac{\partial \rho}{\partial t}=-\nabla \cdot(\rho U)
$$

Momentum equation

$$
\begin{gathered}
\rho\left[\frac{1}{\epsilon} \frac{\partial U}{\partial t}+\frac{1}{\epsilon}(U . \nabla) U \frac{1}{\epsilon}\right]=\frac{1}{\epsilon} \nabla\left(\mu\left(\nabla U+(\nabla U)^{T}\right)\right)+ \\
\rho g-\mu \beta^{-1}
\end{gathered}
$$

Mass transport

$$
\begin{aligned}
& \frac{\partial\left(\epsilon C_{n}\right)}{\partial t}+U \cdot \nabla C_{n}=\nabla\left(D_{n m} \nabla C_{n}\right)+S_{n} \\
& S_{n}=\frac{1}{\rho_{s}} \frac{\partial q}{\partial t}=\frac{K_{1}}{\rho_{s}}\left(q_{e}-\frac{C_{i}-C}{\rho_{s}}\right)
\end{aligned}
$$

Where $S_{n}$ is adsorption rate which can be substituted by pseudo-first order mechanism, $\mathrm{k}_{1}$ is first order constant and $\mathrm{q}_{\mathrm{e}}$ is capacity loading in equilibrium state. The experimental parameters $\mathrm{k}_{1}$ and $\mathrm{q}_{\mathrm{e}}$ are function of temperature which is derived from Kasaini et al., [2013] as data set of Nickel ions removal. The removal $\%$ can be expressed as following:

$$
\text { removal } \%=\frac{C_{i}-C}{C_{i}} \times 100
$$

Energy equation

$$
\rho C p \frac{\partial T}{\partial t}+\rho C p U . \nabla T=\nabla(-k \nabla T)
$$

All the physical properties of fluid $(\varrho, \mu, \mathrm{K}$ and $\mathrm{Cp}$ ) are scheduled in COMSOL Multiphysics database which are function of temperature. In present work, the water is taken as an effluent fluid. The geometry and mesh analysis can be seen in figure 1 , the dimension of adsorption is $450 \mathrm{~mm}$, the total height of column is $500 \mathrm{~mm}$ and the column diameter is $100 \mathrm{~mm}$. The column has one inlet stream in the top of column and two outlet streams in 250 $\mathrm{mm}$ height and in the bottom of column, the upper outlet stream line can be recycled to feed tank to control pressure, velocity, temperature and concentration of adsorption bed. The mesh analysis is generated automatically by set the mesh size as normal size according to geometry and the used physics especially fluid flow. The boundary conditions and operational parameters is illustrated in table 1. 
Table 1: the used variables in present investigation.

\begin{tabular}{|c|c|c|}
\hline $\begin{array}{c}\text { Operational parameters and } \\
\text { boundary conditions }\end{array}$ & Symbol & values \\
\hline Inlet flow rate & $\mathrm{F}$ & $\begin{array}{c}80-200 \\
\mathrm{ml} / \mathrm{min}\end{array}$ \\
\hline $\begin{array}{c}\text { Inlet temperature } \\
\begin{array}{c}\text { Inlet concentration of heavy } \\
\text { metal }\end{array}\end{array}$ & $\mathrm{T}_{\mathrm{i}}$ & $30-50 \circ \mathrm{C}$ \\
\hline Porosity & $\varepsilon$ & $0.1-1 \mathrm{M}$ \\
\hline Permeability & $\beta$ & $10^{-12} \mathrm{~m}^{2}$ \\
\hline $\begin{array}{c}\text { Diffusivity of heavy metal in } \\
\text { porous media }\end{array}$ & $\mathrm{D}_{\mathrm{nm}}$ & $\begin{array}{c}10^{-9} \\
\mathrm{~m}^{2} / \mathrm{s}\end{array}$ \\
\hline $\begin{array}{c}\text { Porous media density } \\
\mathrm{kg} / \mathrm{m}^{3}\end{array}$ \\
\hline Outlet gauge pressures & $\varrho_{\mathrm{s}}$ & $0 \mathrm{~atm}$ \\
\hline The side walls temperatures & & $20 \circ \mathrm{C}$ \\
\hline \multicolumn{2}{|c|}{}
\end{tabular}
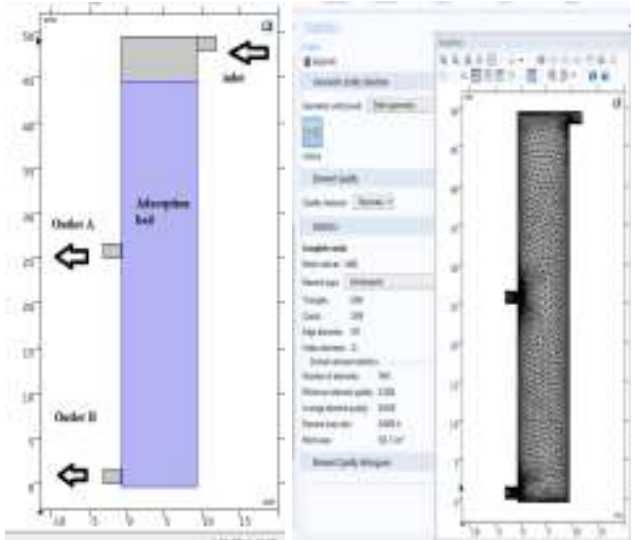

Figure 1: The geometry and mesh analysis by using COMSOL Multiphysics V 5.4 interface.

\section{The contours Analysis}

The numerical solution results are presented as contour view. COMSOL generates frames for each time period of time dependent (transient) transport phenomena physics. For fluid flow, velocity and pressure profiles development are rapid, the steady state development can be achieved in parts of second time period. As shown in figure 2, the velocity is maximum at the head region of adsorption bed before the entrance of porous media region. The stream lines are shown to describe the flow pattern of fluid through the porous media. For pressure case the pressure starts to be maximum at entrance region and it get reduces through the bed till become near to zero (pressure gauge) in downstream. The heat transfer and mass transfer convection depend mainly upon velocity distribution, and takes the same flow trajectory as shown in figure 2. The time dependent of temperature and concentration profiles are too clear and they need too high time to achieve the steady state because of their physical molecular and physical lump capacitance properties.

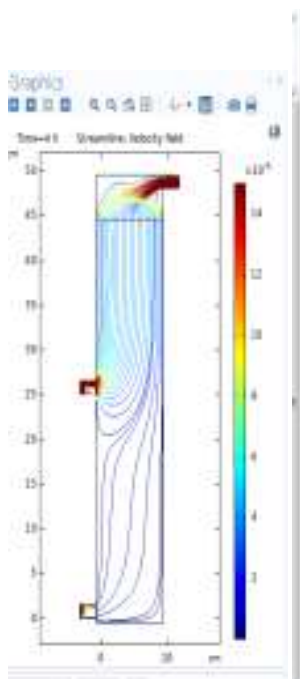

a. velocity stream line

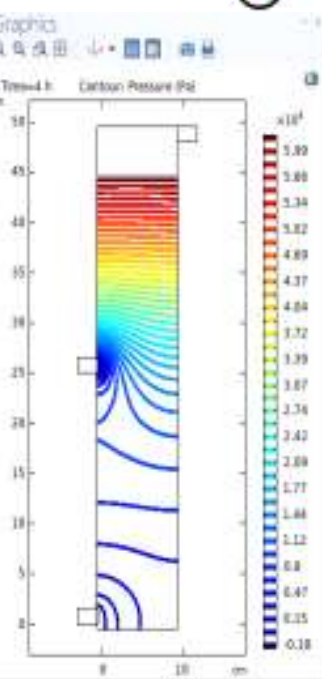

b. pressure contour.

Figure 2: Steady state velocity and pressure profiles through adsorption bed.

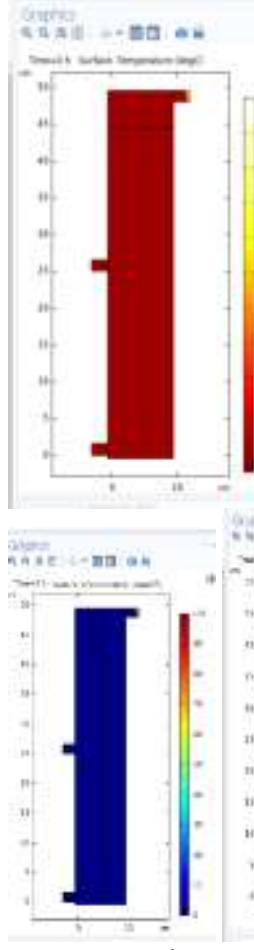

a. $\mathrm{t}=0 \mathrm{~h}$

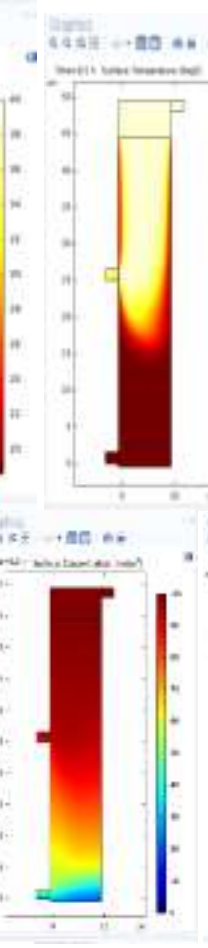

b. $\mathrm{t}=0.5 \mathrm{~h}$

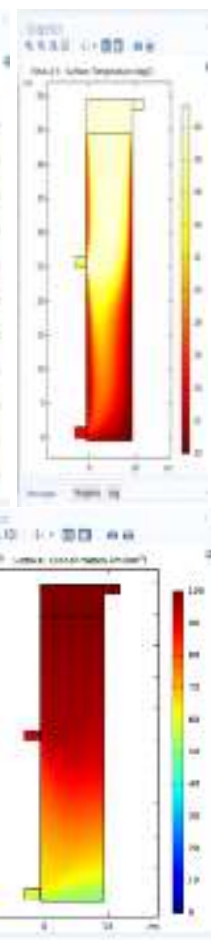

c. $\mathrm{t}=2 \mathrm{~h}$

Figure 3: time dependent of temperature and heavy metal concentration profiles through adsorption bed within $\mathrm{F}=80 \mathrm{ml} / \mathrm{min}$.

\section{Results and discussion}

\subsection{The effect of inlet concentration on $\mathrm{Ni}$ removal efficiency}

The relation between concentration in porous bulk and time is logarithmic, so is for the relation between the concentration and porous media length which is observed by the simulation of present study. Figures 4 to 6 show the variation of removal \% with time, bed length and inlet concentration when $\mathrm{F}=80$ $\mathrm{ml} / \mathrm{min}$ and $\mathrm{T}_{\mathrm{i}}=40{ }^{\circ} \mathrm{C}$. Each time period has trend of removal \% vs. bed length from the inlet $(50 \mathrm{~cm})$ to the effluent outlet stream $(0 \mathrm{~cm})$. In general, the performance of adsorption bed decreases by increasing time for whole bed in every point in adsorption bed. At $\mathrm{C}_{\mathrm{i}}=0.1 \mathrm{M}$, the first $1 \mathrm{~h}$ gives the 
removal efficiency between $75-100 \%$ while the rest time gives lower efficiency till reaching to the minimum efficiency of $50 \%$. At $\mathrm{C}_{\mathrm{i}}=0.5 \mathrm{M}$, the time between $0-0.6 \mathrm{~h}$ gives the removal efficiency between 75-100\% while the rest time gives lower efficiency till reaches to the minimum efficiency of 10 $\%$ at $\mathrm{t}=3.5 \mathrm{~h}$ while $5 \%$ is achieved at the same time at $\mathrm{C}_{\mathrm{i}}=1 \mathrm{M}$. The previous experimental investigations showed that the increasing of the adsorbent dose leads to increase of uptake load $\mathrm{q}$ for batch process [Paliulis, 2006]. The adsorption process happens rapidly in adsorbate surface in early operation time, the removal efficiency decreases due to the saturation of porous media when the active cites to keep $\mathrm{Ni}$ particles are not enough in high concentrations. The effect of inlet concentration on effluent removal \% (B outlet) for a period time is shown in figure 7 . When the higher concentrations give the lower removal behavior.

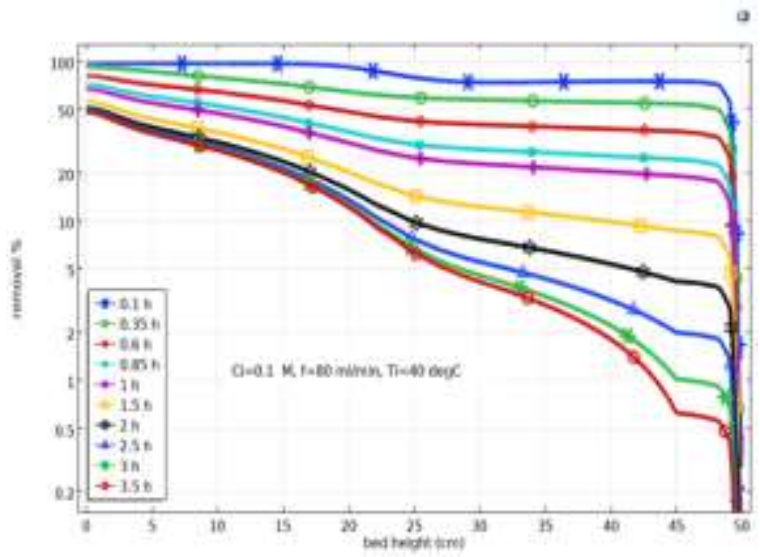

Figure 4: Removal \% vs. bed height for various operation times for $\mathrm{F}=80 \mathrm{ml} / \mathrm{min}, \mathrm{T}=40^{\circ} \mathrm{C}$, and $\mathrm{C}_{\mathrm{i}}=0.1 \mathrm{M}$.

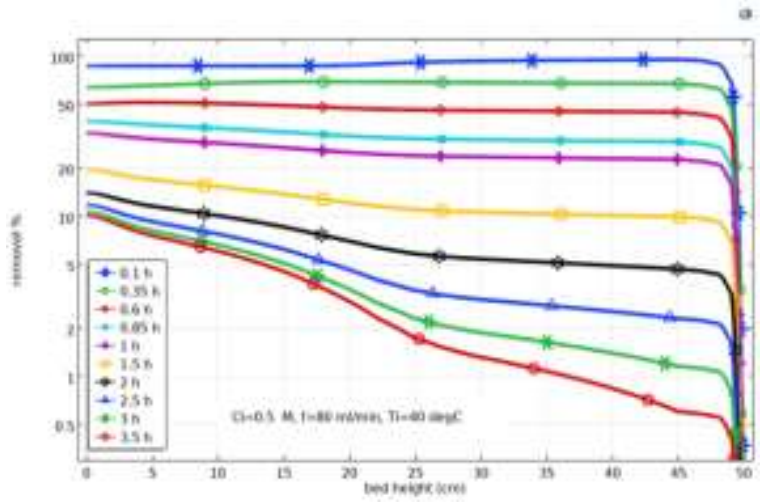

Figure 5: Removal \% vs. bed height for various operation timesat $\mathrm{F}=80 \mathrm{ml} / \mathrm{min}, \mathrm{T}=40^{\circ} \mathrm{C}$ and $\mathrm{C}_{\mathrm{i}}=0.5$ M.

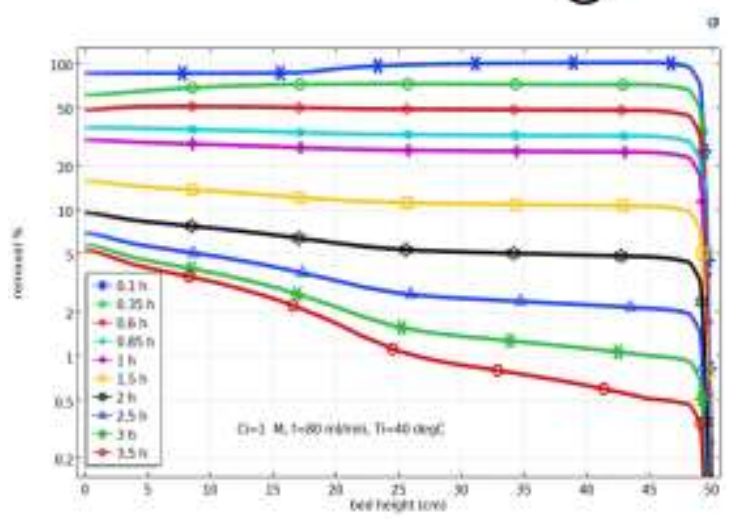

Figure 6: Removal \% vs. bed height for various operation times at $\mathrm{F}=80 \mathrm{ml} / \mathrm{min}, \mathrm{T}=40{ }^{\circ} \mathrm{C}$ and $\mathrm{C}_{\mathrm{i}}=1$ M.

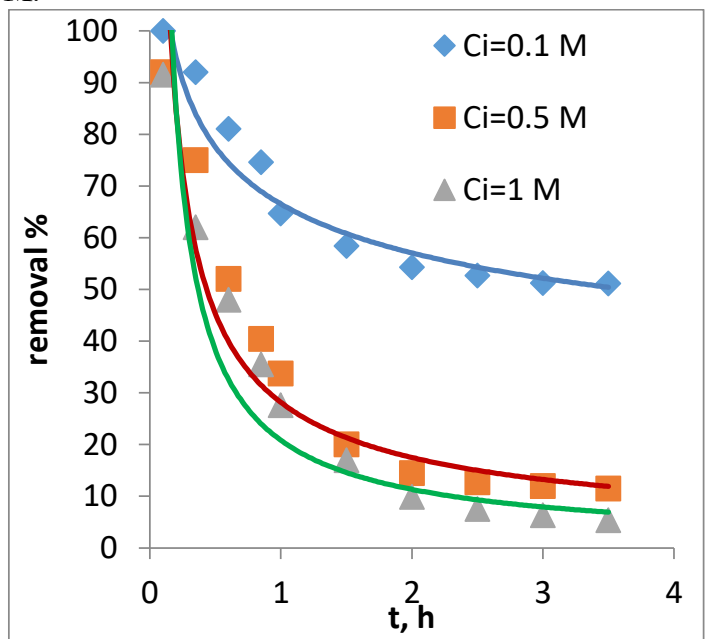

Figure 7: Removal \% vs. time for various inlet concentrations.

\subsection{The effect of inlet temperature on $\mathrm{Ni}$ removal efficiency}

The temperature behavior inside porous media can be shown in figures 8-10. The temperature has the same behavior for whole inlet temperature cases, time and bed heights. The significance can be seen in the magnitude of temperature difference between the inlet stream and A outlet stream can be varied with inlet temperature in direct proportion under steady state changes for whole operation time. The temperature difference magnitude of $1.5,5$ and 9 degrees centigrade can be observed for inlet temperatures of 30,40 and $50 \circ \mathrm{C}$. The magnitude of temperature difference between the region of $\mathrm{A}$ outlet and B outlet is higher than the difference between the inlet and A outlet because the most of inlet flow rates will discharge from A outlet to recycle to inlet again and the rest of bed height is considered heat transfer resistance against the free stream fluid flow of low velocities. For operation time, the drop in temperature trend in the region between $\mathrm{A}$ outlet and $\mathrm{B}$ outlet becomes more sluggish with be height and the becomes more sluggish by the time. 


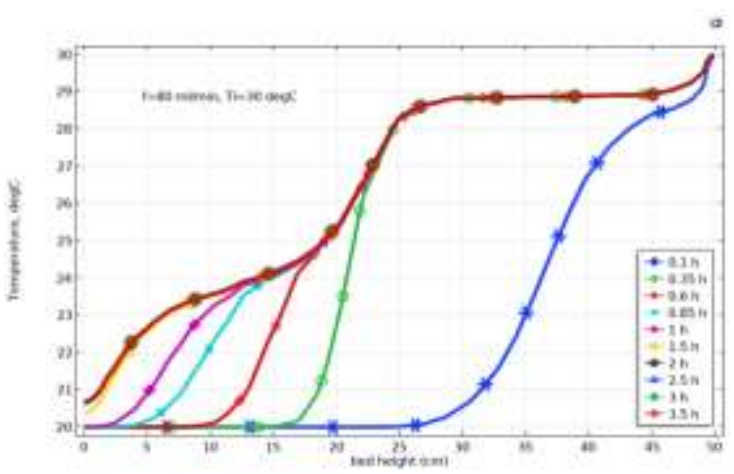

Figure 8: Temperature vs. bed height for various time at $\mathrm{F}=80 \mathrm{ml} / \mathrm{min}, \mathrm{T}=30^{\circ} \mathrm{C}$ and $\mathrm{C}_{\mathrm{i}}=1 \mathrm{M}$.

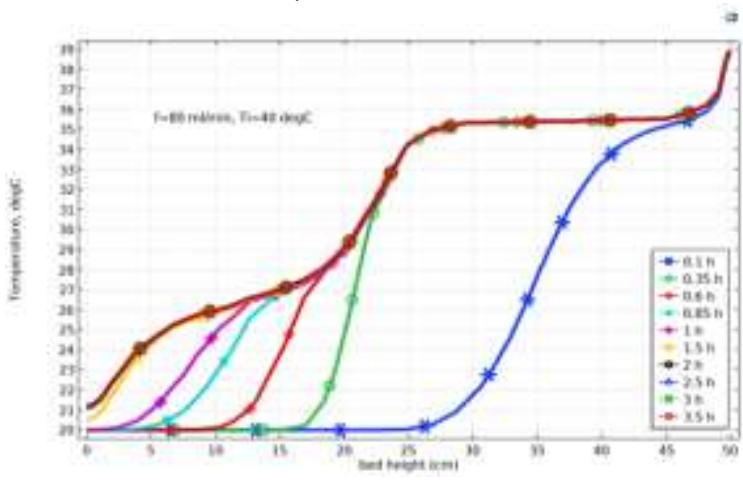

Figure 9: Temperature vs. bed height for various time at $\mathrm{F}=80 \mathrm{ml} / \mathrm{min}, \mathrm{T}=40^{\circ} \mathrm{C}$ and $\mathrm{C}_{\mathrm{i}}=1 \mathrm{M}$.

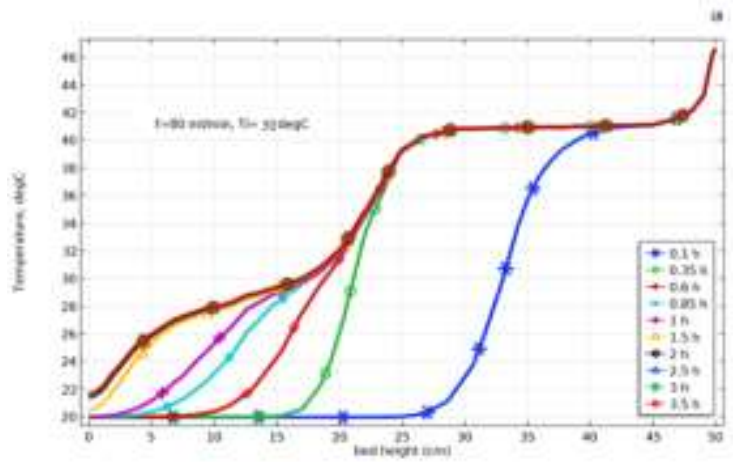

Figure 10: Temperature vs. bed height for various operation times at $\mathrm{F}=80 \mathrm{ml} / \mathrm{min}, \mathrm{T}=50^{\circ} \mathrm{C}$ and $\mathrm{C}_{\mathrm{i}}=1$ M.

The effect of inlet temperature on concentration or removal efficiency can be explained by Eq. (4) when the adsorption rate constants $\left(\mathrm{q}_{\mathrm{e}}\right.$ and $\mathrm{k}_{1}$ ) are function of temperatures, for batch studies Kasaini et al.,[ 2013] found that these constants increases by temperature increasing, and adsorption rate so is. Figures 11 and 12 show the removal \% vs. bed height for various time and inlet temperature at $\mathrm{C}_{\mathrm{i}}=0.1 \mathrm{M}$ and $\mathrm{F}=80 \mathrm{ml} / \mathrm{min}$. At $\mathrm{T}_{\mathrm{i}}=30 \circ \mathrm{C}$, the column removal efficiency will drop to less than $50 \%$ for whole bed height for whole range of operation period time. For $\mathrm{T}_{\mathrm{i}}=50 \circ \mathrm{C}$, the removal efficiency of adsorption bed is higher than $\mathrm{T}_{\mathrm{i}}=40 \circ \mathrm{C}$ for whole ranges of time and bed height. The higher temperatures deform the porous media micro and nano structure which produces more adsorption active size with higher Vander Walls energy, the discussion is based on the comparison between figures 5 and 12 .

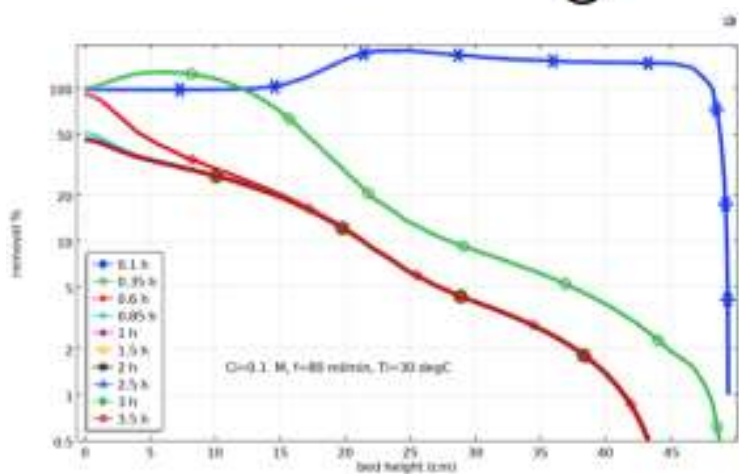

Figure 11: Removal \% vs. bed height for various time at $\mathrm{F}=80 \mathrm{ml} / \mathrm{min}, \mathrm{T}=30^{\circ} \mathrm{C}$ and $\mathrm{C}_{\mathrm{i}}=1 \mathrm{M}$.

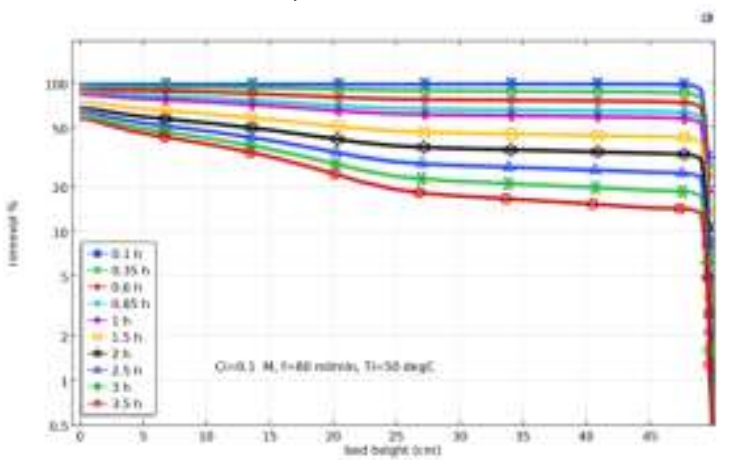

Figure 12: Removal \% vs. bed height for various operation times at $\mathrm{F}=80 \mathrm{ml} / \mathrm{min}, \mathrm{T}=50{ }^{\circ} \mathrm{C}$ and $\mathrm{C}_{\mathrm{i}}=0.1$ M.

\subsection{The effect of inlet flow rate on $\mathrm{Ni}$ removal efficiency}

The impact of flow rates on pressure drop is direct as shown in figures 13 and 14, the pressure varies with the bed length, period time and flow rates. The pressure drops significantly between the inlet region and $\mathrm{A}$ outlet region more than the drop between $\mathrm{A}$ out let region and $\mathrm{B}$ outlet region. The steady state develops at $\mathrm{F}=140 \mathrm{ml} / \mathrm{h}$ faster 4 than $\mathrm{F}=80 \mathrm{ml} / \mathrm{min}$. Figure 14 shows the temperature vs. bed length for various period time operation at $\mathrm{T}_{\mathrm{i}}=40$ ${ }^{\circ} \mathrm{C}$ and $\mathrm{F}=140 \mathrm{ml} / \mathrm{min}$. The comparison between figures 14 and 8 shows that the temperature difference between inlet and $\mathrm{B}$ outlet region in $\mathrm{F}=140$ $\mathrm{ml} / \mathrm{min}$ is 3 degree centered less than $=80 \mathrm{ml} / \mathrm{min}$ case. The drop between the two outlets regions are more sluggish than $\mathrm{F}=80 \mathrm{ml} / \mathrm{min}$. The reason of the impact of flow rate in temperature of adsorption bed is because the increasing in flow rate will shortage the thermal contact time in porous media. Figure 15 illustrates the removal \% vs. bed length for various period time operation at $\mathrm{T}_{\mathrm{i}}=40 \circ \mathrm{C}, \mathrm{C}_{\mathrm{i}}=0.1 \mathrm{M}$ and $\mathrm{F}=140 \mathrm{ml} / \mathrm{min}$. The comparison between figures 16 and 5 shows that the removal efficiency of $\mathrm{F}=140$ $\mathrm{ml} / \mathrm{min}$ is dramatically lower than $\mathrm{F}=80 \mathrm{ml} / \mathrm{min}$, when the adsorption bed will saturate by $\mathrm{Ni}^{+2}$ faster than $\mathrm{F}=80 \mathrm{ml} / \mathrm{min}$. Figure 16 shows the schematic of parameters interaction of transport phenomena in porous media of adsorption bed based on the results of present investigation. 


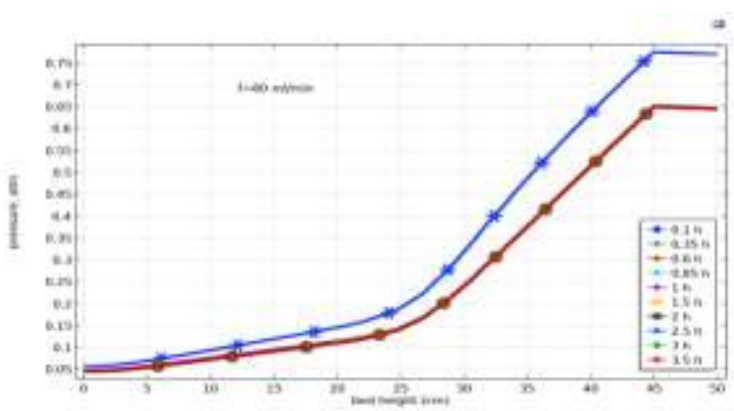

Figure 13: Pressure vs. bed height for various time at $\mathrm{F}=80 \mathrm{ml} / \mathrm{min}, \mathrm{T}=40^{\circ} \mathrm{C}$ and $\mathrm{C}_{\mathrm{i}}=0.1 \mathrm{M}$.

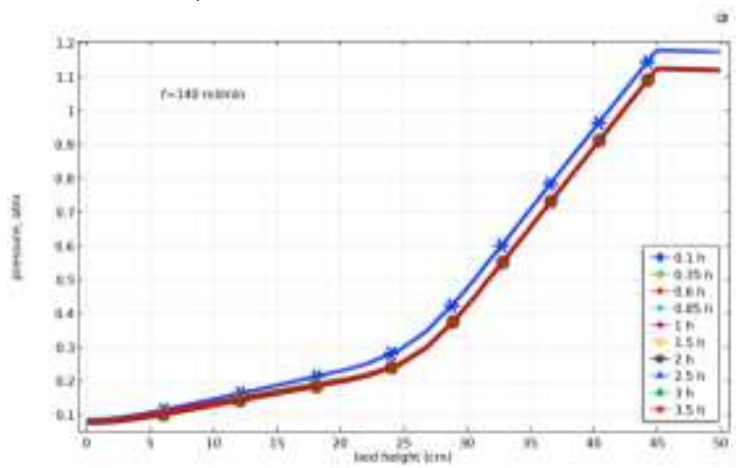

Figure 14: Pressure vs. bed height for various time at $\mathrm{F}=140 \mathrm{ml} / \mathrm{min}, \mathrm{T}=40^{\circ} \mathrm{C}$ and $\mathrm{C}_{\mathrm{i}}=0.1 \mathrm{M}$.

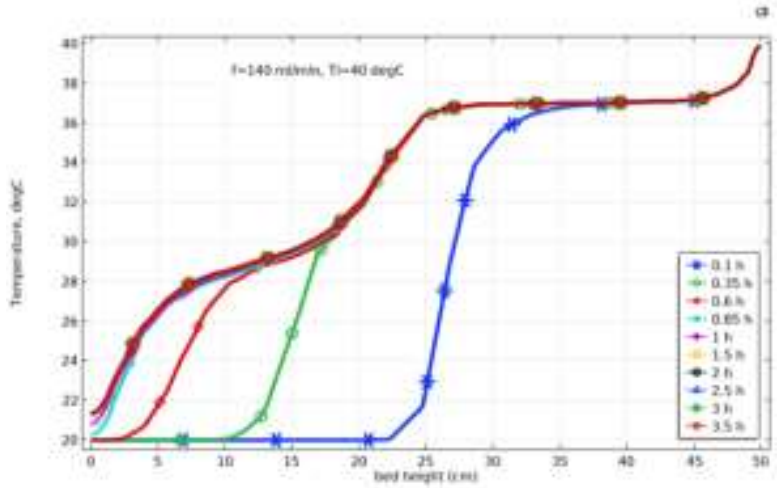

Figure 15: Temperature vs. bed height for various time at $\mathrm{F}=140 \mathrm{ml} / \mathrm{min}, \mathrm{T}=40{ }^{\circ} \mathrm{C}$ and $\mathrm{C}_{\mathrm{i}}=0.1 \mathrm{M}$.

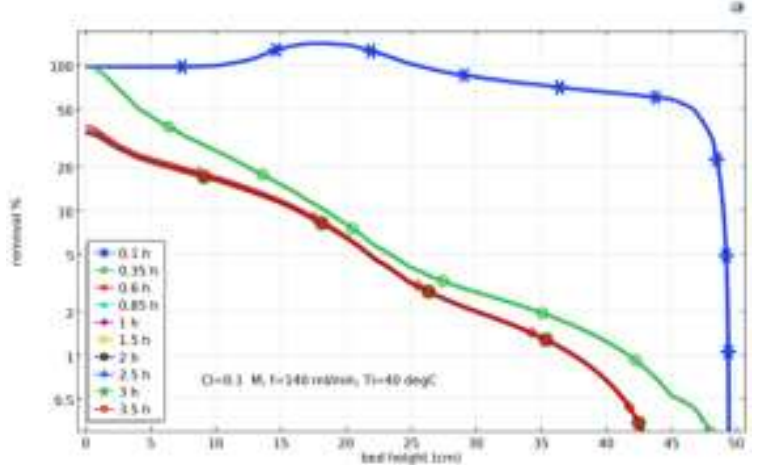

Figure 16: Removal \% vs. bed height for various time at $\mathrm{F}=140 \mathrm{ml} / \mathrm{min}, \mathrm{T}=40^{\circ} \mathrm{C}$ and $\mathrm{C}_{\mathrm{i}}=0.1 \mathrm{M}$.

Table 2 shows the comparison of adsorption operation condition with different parameters and to show the optimal condition in which the \% removal will be maximize. The highest removal $\%$ is achieved at operation conditions of $\mathrm{Ti}=50{ }^{\circ} \mathrm{C}, \mathrm{Ci}=0.1 \mathrm{M}$ and $\mathrm{F}=80 \mathrm{ml} / \mathrm{min}$. The correlated expression has been obtained by applying $\mathrm{R}$ software package on the data from table 2 , the data is undergone non-linear regression to express the behaviors of removal $\%$ for various operating conditions as expressed in follows:

$$
\begin{gathered}
\text { removal } \%=23.75 C i^{-0.9736} F^{-0.62614} \mathrm{Ti}^{0.6319} \\
\quad \ldots . .(7) \\
\mathrm{R}^{2}=99.9 \% \\
\mathrm{Rss}=0.425 \%
\end{gathered}
$$

Table 2: The comparison of adsorption operation condition with different parameters and to show the optimal removal conditions

\begin{tabular}{|c|c|c|c|}
\hline $\begin{array}{c}\text { Concentr } \\
\text { ation, } \mathbf{M}\end{array}$ & $\begin{array}{c}\text { Inlet flow } \\
\text { rate, } \mathbf{~ m l / m i n}\end{array}$ & $\begin{array}{c}\text { Inlet } \\
\text { temperatur } \\
\mathbf{e},{ }^{\circ} \mathbf{C}\end{array}$ & $\begin{array}{c}\text { Outlet } \\
\text { removal } \\
\mathbf{\%}\end{array}$ \\
\hline 0.1 & 80 & 40 & 51.1 \\
\hline 0.5 & 80 & 40 & 11.5 \\
\hline 1 & 80 & 40 & 5.4 \\
\hline 0.1 & 80 & 30 & 47.6 \\
\hline 0.1 & 80 & 50 & 57.4 \\
\hline 0.1 & 140 & 40 & 36.8 \\
\hline
\end{tabular}

\section{Conclusion}

The computational fluid dynamic modeling and simulation of Nickel removal in adsorption bed by using COMSOL Multiphysics is successfully investigated. The velocity streamlines, pressure lines, temperature and concentration profiles for various period time have been developed. The optimal adsorption operation conditions occur when $\mathrm{F}=80$ $\mathrm{ml} / \mathrm{min}, \mathrm{T}_{\mathrm{i}}=50{ }^{\circ} \mathrm{C}$ and $\mathrm{C}_{\mathrm{i}}=0.1 \mathrm{M}$. The removal efficiency is above $50 \%$ in first $2 \mathrm{~h}$ for the whole bed length, the effluent stream (B outlet) are kept to obtain removal efficiency above than $50 \%$ for whole time interval. The effect of flow rate, temperature and the interaction on removal efficiency is briefly discussed and interpreted. The numerical model can be used to enhance modeling of adsorption process for non-isothermal process, to fulfill the real time operation. The high flow rates, high concentration, and low temperature shorten the operating time of adsorption bed for a certain length. By this model, the adsorption bed designers will take the transport

\begin{tabular}{|c|c|c|}
\hline \multicolumn{3}{|c|}{ Nomenclature } \\
\hline symbol & meaning & unit \\
\hline $\mathrm{C}$ & $\begin{array}{l}\text { Heavy metal } \\
\text { concentration }\end{array}$ & $\mathrm{M}$ \\
\hline $\mathrm{T}$ & Temperature & ${ }^{\circ} \mathrm{C}$ \\
\hline $\bar{U}$ & Fluid velocity & $\mathrm{m} / \mathrm{s}$ \\
\hline$q$ & Loading capacity & $\mathrm{mg} / \mathrm{g}$ \\
\hline K & $\begin{array}{c}\text { Thermal } \\
\text { conductivity }\end{array}$ & $\mathrm{W} / \mathrm{m} \cdot{ }^{\circ} \mathrm{C}$ \\
\hline $\mathrm{Cp}$ & Heat capacity & $\mathrm{J} / \mathrm{kg} \cdot{ }^{\circ} \mathrm{C}$ \\
\hline $\mathrm{F}$ & Flow rate & $\mathrm{ml} / \mathrm{min}$ \\
\hline $\mathrm{S}$ & Adsorption rate & $\mathrm{M} / \mathrm{s}$ \\
\hline $\mathrm{D}$ & diffusivity & $\mathrm{m}^{2} / \mathrm{s}$ \\
\hline$g$ & $\begin{array}{c}\text { Gravity } \\
\text { acceleration }\end{array}$ & $\mathrm{m} / \mathrm{s}^{2}$ \\
\hline
\end{tabular}
phenomena considerations to enhance adsorption bed performance through modeling, design and operation. 


\begin{tabular}{|c|c|c|}
\hline \multicolumn{3}{|c|}{ Greek letters } \\
\hline symbol & meaning & unit \\
\hline$\varrho$ & Density & $\mathrm{Kg} / \mathrm{m}^{3}$ \\
\hline$\mu$ & viscosity & $\mathrm{Pa} . \mathrm{s}$ \\
\hline$\epsilon$ & porosity & \\
\hline$\beta$ & Permeability & $\mathrm{m}^{2}$ \\
\hline
\end{tabular}

\begin{tabular}{|c|c|}
\multicolumn{2}{c}{ Subscript } \\
\hline symbol & meaning \\
\hline $\mathrm{i}$ & Density \\
\hline $\mathrm{n}$ & Heavy metal \\
\hline $\mathrm{m}$ & fluid \\
\hline $\mathrm{s}$ & Solid particles of porous media \\
\hline
\end{tabular}

\section{References}

[1] Harasim, P. and Filipek, T. (2015) "Nickel in the environment," Journal of Elementology, 20(2), pp. 525-534. doi: 10.5601/jelem.2014.19.3.651.

[2] Shrestha, R. M. (2016) "Removal of Cd (II) ions from Aqueous Solution by Adsorption on Activated Carbon Prepared from Lapsi (Choerospondias axillaris) Seed Stone," Journal of the Institute of Engineering, 11(1), p. 140. doi: 10.3126/jie.v11i1.14708.

[3] Yahaya Ahmed Iyaka (2011) "Nickel in soils: A review of its distribution and impacts," Scientific Research and Essays, 6(33), pp. 6774-6777. doi: 10.5897/SREX11.035.

[4] Bennett, B. G. (1982) "Exposure of man to environmental nickelan exposure commitment assessment," sci- environ, 22(3), p. 203.

[5] Salt D. E., Blaylock, M.,Kumar, N., Dushenkov, V., Ensley, B., Chet, I., Raskin, I., (1995) "Phytoremediation: a novel strategy for the removal of toxic metals from the environment using plants.," Biotechnology, 13(5), pp. 468-474.

[6] Duda-Chodak, A. and Blaszczyk, U. (2008) “The Impact of Nickel on Human Health.," Journal of Elementology, 13(4), pp. 685-696.

[7] Lakherwal, D. (2014) "Adsorption of Heavy Metals: A Review," International Journal of Environmental Research and Development, 4(1), pp. 2249-3131. doi: 10.1007/s11270-007-9401-5.

[8] Regina, M. Y., Saraswathy. S., Balu, K., Karthik, V., Muthukumaran, K., (2015) "Removal of nickel (II) ions from waste water using low cost adsorbents:A review," Journal of Chemical and Pharmaceutical Sciences, 8(1), pp. 1-6.

[9] Rađenović, A., Malina, J. and Štrkalj, A. (2011) "Removal of $\mathrm{Ni}$ (II) from aqueous solution by low-cost adsorbents," The Holistic Approach to Environment, 1(3), pp. 109-120.

[10] Goyal, R. C. and Bansal M. (2005) Activated Carbon Adsorption. London. Taylor and Fracis Group.

[11] Ajmal, M. , Rao, R. A. K., Ahmad, R. , Ahmad, J.,(2000) “Adsorption studies on Citrus reticulata (fruit peel of orange): removal and recovery of $\mathrm{Ni}(\mathrm{II})$ from electroplating wastewater," Journal of Hazardous Materials, 79(1), pp. 117-131.

[12] Faur-Brasquet, C., Reddad, Z., Kadirvelu, K ., Le-Cloirec, p.,(2002) "Modeling the adsorption of metal ions $(\mathrm{Cu} 2+, \mathrm{Ni} 2+, \mathrm{Pb} 2+)$ onto ACCs using surface complexation models," Applied Surface Science. North-Holland, 196(1-4), pp. 356-365. doi: 10.1016/S0169-4332(02)00073-9.

[13] Mavrov V., Erwea, T., Blöcherb, C., Chmielb, H.,(2003) "Study of new integrated processes combining adsorption, membrane separation and flotation for heavy metal removal from wastewater.," Desalination, 157(1), pp. 97-104.

[14] Malkoc, E. and Nuhoglu, Y. (2005) "Investigations of nickel(II) removal from aqueous solutions using tea factory waste.," Journal of Hazardous Materials, 127, pp. 120 128.

[15] Kobya, M.,Demirbasb, E., Senturka, E., Incea, M.,(2005) "Adsorption of heavy metal ions from aqueous solutions by activated carbon prepared from apricot stone," Bioresource technology, 96(13), pp. 1518-1521.

[16] Chen, C., Hou, J., Shao, D., Li, J., Wang, X., (2009) "Behavior of multiwall carbon nanotube/ iron oxide magnetic composites for $\mathrm{Ni}(\mathrm{II})$ and Sr(II).," Journal of Hazardous Materials, 164, pp. 923-928.

[17] Byeon, S. H., Kavitha, D., Ponvel, K., Kim, K., Lee, c.,(2009) "Surface modified granular activated carbon for enhancement of nickel adsorption from aqueous solution," Korean Journal of Chemical Engineering, 26(6), pp. 1748-1753. doi: 10.1007/s11814-009-0274-8.

[18] Kasaini, H., Kekana, P. T., Saghti, A. A., Bolton, K., (2013) "Adsorption Characteristics of Cobalt and Nickel on Oxalate-Treated Activated Carbons in Sulphate Media," World Academy of Science, Engineering and Technology, 76(Ii), pp. 707-721.

[19] Lakherwal, D., Rattan, V. K. and Singh, H. P. (2016) "Studies on Adsorption of Nickel by Activated Carbon in a Liquid Fluidised Bed Reactor," Canadian Chemical Transactions, 4(1), pp. 121-132. doi: 10.13179/canchemtrans.2016.04.01.0264.

[20] Ben-Ali, S., Jaouali, I., Souissi-Najar, S., Ouederni, A. M., (2017) "Characterization and adsorption capacity of raw pomegranate peel biosorbent for copper removal," Journal of Cleaner Production. Elsevier Ltd, 142, pp. 3809_ 3821. doi: 10.1016/j.jclepro.2016.10.081.

[21] Tasker, S. Z., Standley, E. A. and Timothy F. Jamison (2015) "Recent Advances in Nickel Catalysis," Nature, 509(7500), pp. 299-309. doi: 10.1021/cb400577b.Antibacterial.

[22] Abdel-Shafy, H. I., Abdel-Sabour, M. F. and Aly, R. O. (1998) "Adsorption of nickel and mercury from drinking water simulant by activated carbon," Environmental Management and Health, 9(4), pp. 170-175. doi: 10.1108/09566169810228999.

[23] Qasim, S. R. (2000) Water works engineering. Dalas- Texas: Printice Hall PTR.

[24] Kadirvelu, K., Faur-Brasquet, C. and Le Cloirec, P. (2000) "Removal of $\mathrm{Cu}(\mathrm{II}), \mathrm{Pb}(\mathrm{II})$, and $\mathrm{Ni}(\mathrm{II})$ by adsorption onto activated carbon cloths," Langmuir, 16(22), pp. 8404-8409. doi: 10.1021/la0004810. 
[25] Karnib, M., Kabbanib, A., Holaila, H., Olama, Z.,(2014) "Heavy metals removal using activated carbon, silica and silica activated carbon composite," Energy Procedia. Elsevier B.V., 50, pp. 113-120. doi: 10.1016/j.egypro.2014.06.014.

[26] Paliulis, D. (2006) "Numerical modeling of kinetics of heavy metal sorption from polluted water," Journal of Environmental Engineering and Landscape Management, 14(1), pp. 10-15. doi: 10.1080/16486897.2006.9636873.

[27] Tapia, A. O. and Diaz-viera, M. A. (2008) “A Numerical Simulation of Adsorption Using NonStandard Isotherm Equations in COMSOL A Numerical Simulation of Adsorption Using NonStandard Isotherm Equations in COMSOL," (October).

[28] Nouh, S. A., Lau, K. K. and Shariff, A. M. (2010) "Modeling and simulation of fixed bed adsorption column using integrated CFD approach," Journal of Applied Sciences, 10(24), pp. 3229-3235. doi: $10.3923 /$ jas.2010.3229.3235.

[29] Elgworth, D. (2014) “Adsorptive Desulfurization of Liquid Hydrocarbons: Langmuir Adsorption Modeling Using COMSOL," COMSOL Comference, pp. 1-16.

[30] Saad, N., Abd Ali, Z. T., Naji, L. A.,Faisal, A. A. H., Al-Ansari, N., (2019) "Development of BiLangmuir model for description initial $\mathrm{pH}$ and temperature effects on the sorption of cadmium onto waste foundry sand," Environmental Engineering Research, pp. 0-2. doi: 10.4491/eer.2019.277. 